\title{
Troglobius coprophagus, a new genus and species of cave Collembola from Madagascar, with notes on its ecology
}

\author{
José G. Palacios-Vargas * and Jane Wilson **
}

\begin{abstract}
SUMMARY
Troglobius coprophagus n. g., n. sp. a cave Collembola from Madagascar is characterized by an elongate and serrate mucro, a non spines dens. Description and illustrations of the new genus and species are given. Some ecological data of this highly cave adapted species is also included.
\end{abstract}

Much excellent work has been published on the Symphypleona of Madagascar (Betsch, 1980) but the Arthropleona Collembola, which make up most of the order and are most often found in caves, have received little attention. Indeed, only about eight species have been recorded from Madagascar (Börner, 1907; 1913; Denis, 1925 and 1929; Delamare-Deboutteville, 1948).

Ankarana is a small limestone massif in the extreme north of Madagascar, about $70 \mathrm{~km}$ south of Antsiranana (Diego-Suarez). The 98 $\mathrm{km}$ of surveyed passages within it represent the largest and most extensive cave systems in Madagascar and probably.in the whole tropical Africa. These numerous caves provide many diverse subterranean habitats for cave adapted animals. Some passages, dried to a humidity of only $50 \%$ by through draughts, contain $10 \mathrm{~m}$ high guano beds dominated by Periplaneta americana while others are filled with clean silt and the humidity approaches $100 \%$.

In 1981 members of a Southampton University Expediton (Wilson, 1985; Wilson, 1987a), carried out the first study of the ecology of a D.F

* Ecologia de Microartrópodos, Dep. Biologia, Fac. Ciencias, UNAM. 04510 Mèxico, ** Department of Paediatrics, John Radcliffe Hospital, Headington, Oxford, 0X3 9DU, U.K. 
Malagasy cave and at this time collected two new Troglopedetine cave-adapted Collembola. Further field work was carried out in 1986 by members of the Crocodile Caves of Ankarana Expedition (Wilson, 1987b). One Collembola species, Troglopedetes madagascarensis has been described elsewhere (Wilson, 1982). The other did not fit into any known genus and is described here.

The richest site for collecting both Troglopedetes madagascarensis (Cyphoderopsis madagascarensis, after Thibaud \& Najt, 1988), and the new genus and species, was in the dark zone of the $11 \mathrm{~km}$ cave known as La Grotte d'Andrafiabè. About one kilometre into this cave is a roost of several hundred leaf-nosed bats Hipposideros commersoni and beneath this roost there is an abundance of organic material (guano and carcasses) which anables fungi to grow. This provides food for the Collembola and other detritivores. Sympatric invertebrates on these guano beds included other'Collembola: Isotomiella minor and a species close to Xenylla yucatana Mills, 1938; also woodlice: Synarmadillo madagascariensis, and undescribed troglobitic millepedes. These detritivores fall prey to mites, ants (Pheidole megacephala), and pigmented centipedes (Cormocephalus lambertoni).

At this particular site in the cave, the temperature is constant at about $25^{\circ} \mathrm{C}$ and the humidity is almost $100 \%$. The two Collembola are active, white, glistening, insects which are able to jump $5 \mathrm{~cm}$ with ease. They were observed grazing on fungi, specially that growing on bat carcasses. Collembola cease moulting when starved, so the finding of abudant exuvae at this site indicates that they are gaining adecuate nutrition from this source.

Living examples of both species were kept at ambient temperatures and $100 \%$ humidity by putting them in small containers lined with damp plaster of Paris mixed with charcoal. These where kept cool in the shade of the cave entrance, but both $C$. madagascarensis and the new Troglobius coprophagus died within 24 hours of being brought out to the entrance zone implying they are very temperature sensitive.

The two Collembola were found, in lesser numbers, in other locations within caves of the Ankarana limestone massif were the humidy was around $100 \%$ and fungus was growing.

\section{Troglobius n. gen.}

\section{Diagnosis}

The new genus can be differentiated from other Paronelids because: in the labial chaetotaxy there is not setae " $r$ "; the mucro is elongate, with many serrations, and the dens lacks rows of spines.

\section{Type species}

Troglobius coprophagus, n.g., n. sp. from Grotte d'Andrafiabè, Ankarana, Antsirananana, North Madagascar. 


\section{Discussion}

All the known species of Troglopedetes, s.l. (Cf. Palacios-Vargas, Ojeda \& Christiansen, 1985; Wilson, 1982), have one or two rows of dorsal spines on the dens, the new genus Troglobius lacks such spines, and only has setae and scales. Old Word species of Troglopedetes, have antennal segment IV subdivided (recently Thibaud \& Najt, 1988 have confined the Troglopedetes to the species with Ant. IV subdivided). The new genus also has a sub-divided fourth antennal segment. Labial chaetotaxy is more similar to some Pseudosinella than to the paronellids or cyphoderids.

Perhaps this genus deserves the creation of a new tribe between the Cyphoderidae and Paronellidae, but a revision of the group is necessary first.

Troglobius coprophagus n. sp. (Figs. 1-11)

\section{Description}

Habitus of Cyphoderidae (Entomobryoidea) (Fig. 1). Length 1.4 $\mathrm{mm}(0.9-1.4 \mathrm{~mm})$. Blind without pigment. Body with smooth or ciliated setae, scales and some trichobothria. Antennae with sensillae of different size and shape.

Ratio of antenna to head $=1.7: 1.0$ and antenna to body length $=$ $1: 2.3$ Antenna without scales. Ratio of antennal segments I-IV as = $1: 1.2 ; 5.6 ; 13.3$ (i.e. $5 \% ; 6 \% ; 27 \% ; 63 \%$ ). Ant. II with some sensilla differentiated (Fig. 2), as in Troglopedetes. Sensory organ of Ant. III, with two different microsensilla (Fig. 3). Ant. IV unsegmented, with rows of setae and sensilla, without apical bulb.

Head without any trace of eyes or pigment, with two pairs of trichobothria. Labrum with 4 rows of smooth setae (Fig. 6); all the setae are smooth. Labral formula is: 4:5/5/4. Labial triangle with four smooth setae on row A. In posterior row, there is no seta " $r$ ". Posterior setae smooth can be named: M1, M2, E, L1 and L2 (Fig. 4).

Distribution of body trichobothria is two on the second segment and three on the third and fourth abdominal segments (Fig. 1). Head, thorax, abdomen, and furcula with scales. Legs with ciliated setae. Coxa of leg with one large seta. Trochanteral organ with at most 17 setae (Fig. 9). Tenent hairs are shorter than ventral unguis and acuminate (Fig. 7); unguis with two inner basal winged teeth of different size; no median inner teeth and with a very small outer tooth. Unguiculus with outer lamella very developed and the inner small (Figs. 7 and 8).

Posterior part of ventral tube with several long setae and 4 distal pairs of small setae; anterior part with only two pairs of very large setae (Fig. 5). Tenaculum with $4+4$ teeth and only one ciliated setae on the corpus (Fig. 10). Furcula composed of manubrium, dens and mucro in the ratio $5.7 ; 3.4 ; 1.0$ (i.e. $56 \% ; 34 \% ; 10 \%$ ). Dens without spines, but 


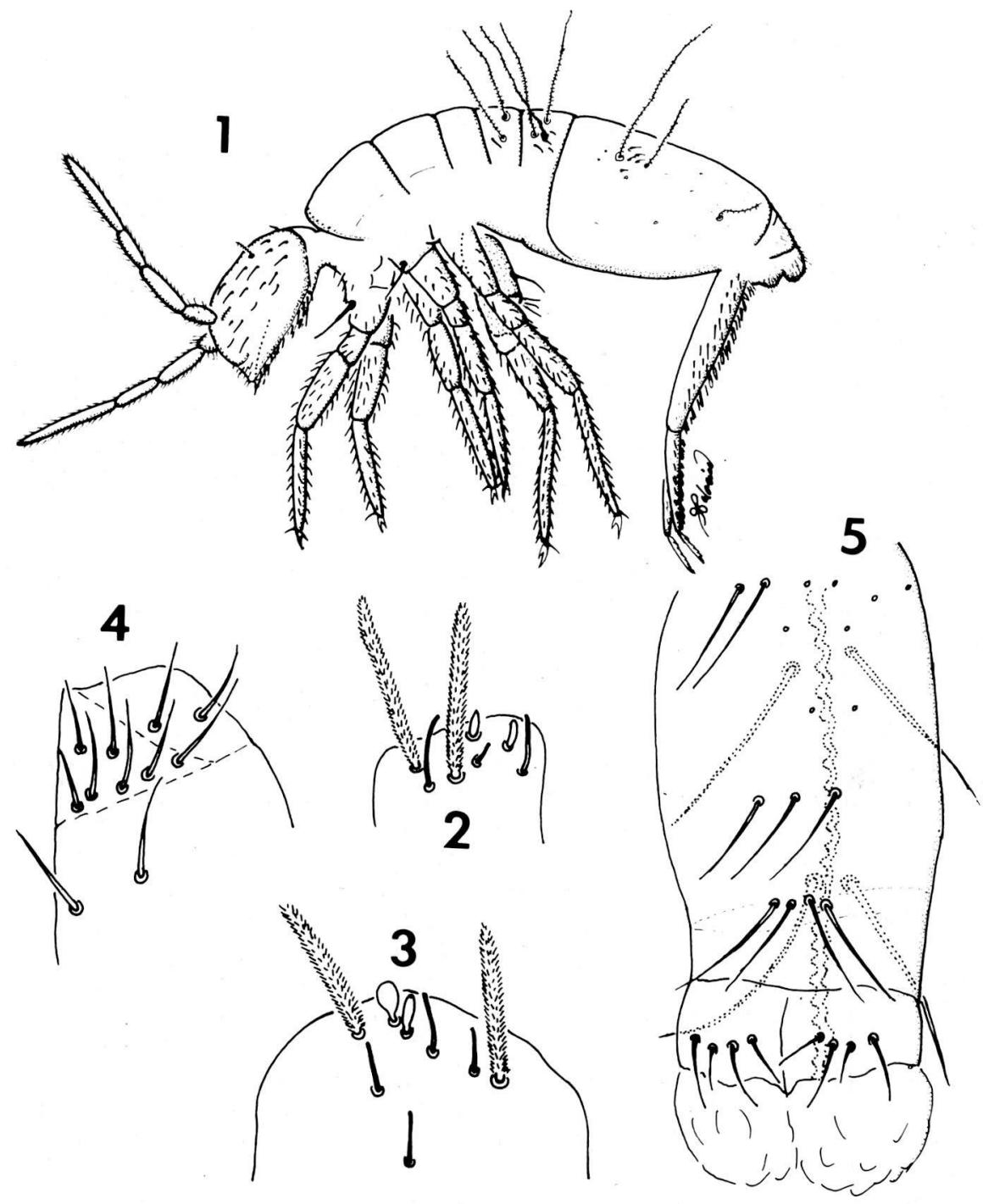

Figs. 1-5 - Troglobius coprophagus n. gen. n. sp. 1, habitus; 2, sensorial organ of Ảnt. II; 3, sense organ of Ant. III; 4, labial triangle; 5, ventral tube. 


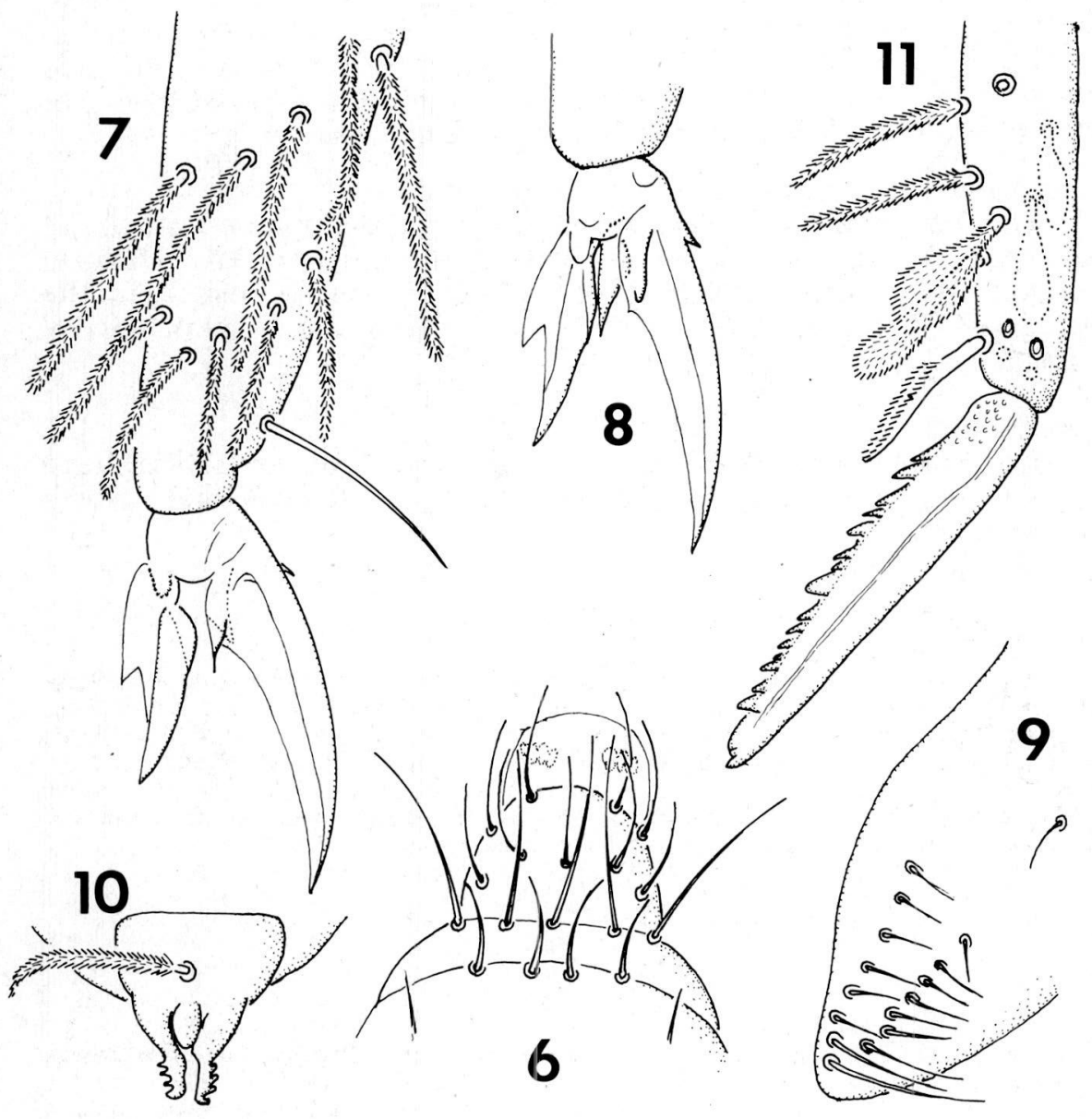

Figs. 6-11 - Troglobius coprophagus n. gen. n. sp. 6, labrum; 7, tibiotarsus and claw of leg I; 8, unguis and unguiculus of leg I; 9, trochanteral organ; 10, tenaculum; 11, distal part of dens and mucro. 
with ciliated setae and scales. Mucro is elongated and bears four large teeth, and numerous serrations, from 8 to 24 .

\section{Discussion}

Troglobius coprophagus lacks eyes and pigment, and has a highly modified foot complex. Like some cave species of Troglopedetes, and Pseudosinella has ungues without inner median teeth, and a relative short and acuminate tenent hair. Consideration of these features, combined with the difficulties of maintaining them outside of the cave environment, leads us to assume that Troglobius coprophagus is a troglomorphic species, highly adapted to life in caves.

\section{Type material}

The holotype and 8 paratypes are held the senior author, 19 paratypes are deposited at the British Museum (Natural History) London (Brit. Mus. 1982-160) and 12 have been deposited in the Malagasy National Collection, Parc Tsimbazaza, Antananarivo, Madagascar.

\section{Type locality}

La Grotte d'Andrafiabè cave system, about $4 \mathrm{~km}$ from Andrafiabè village, Ankarana Massif; $70 \mathrm{~km}$ south of Antsiranana, North Madagascar.

\section{ACKNOWLEDGEMENTS}

The authors wish to express their gratitude to Dr. Peter F. Bellinger, California State University, Northridge, California, Dr. Kenneth A. Christiansen, Grinnel College, Iowa, Dr. Jose A. Mari Mutt, University of Puerto Rico, Mayaguëz, Puerto Rico, and Dr. R. Yoshii (Japon) for the review of the manuscript. The Collembola were collected by J. M. Wilson during two field trips as part of the 1981 Southampton University Madagascar Expedition and the 1986 Crocodile Caves of Ankarana Projetc. Sponsors and supports of these two projects are fully acknowlegded in publications cited below.

\section{LITERATURE CITED}

BESTCH, J.-M. 1980. Elèments pour une monographie des collemboles Symphyplèones (Hexapodes, Aptèrygotes). Mèm. Mus. natn. Hist. nat. (Paris) (A) 116: 1-205.

BÖRNER, C. 1907. Collembolen aus Ostrafrika und Sud America. In Voeltzskow, Reise in Ostrafrika in der Jahre 1903-1905 (Stuttgard) 11: 147-177.

BÖRNER, C. 1913. Zur collembolenfauna Java. Tijdschr. v. entom. (Netherlands) 56: 44-61.

DELAMARE DEBOUTEVILLE, C. 1948. Collemboles de Madagascar. Bull. soc. entom. France 53 (3/4): 38-46.

DENIS, J. R. 1925. Sur deux Collemboles de Madagascar. Bull. Mus. Nat. Hist., Paris 5: 104-1-6. -

MILLS, H. B. 1938. Collembola of Yucatan caves. Carnegie Inst. Wash., Publ. 491: 183-190. 
PALACIOS-VARGAS, J.G., M. OJEDA \& K.A. CHRISTIANSEN. 1985. Taxonomia y Biogeografia de Troglopedetes (Collembola: Paronellidae) en Amèrica, con ènfasis en las especies cavernicolas. Folia. Entomol. Mex. 65: 3-35.

THIBAUD, J. M. \& J. NAJT. 1988. Collembola (Insecta) de l'Equateur. IV. Paronellidae avec rèvision de quatre genres. Bull. Mus. natn. Hist. nat., Paris (4a.) 10, Sect. A. (4): 719-730.

WILSON, J. M. 1982. A review of world Troglopedetini (Insecta, Collembola, Paronellidae) including an identification table and descriptions of new species. Cave Science 9 (3): $210-226$.

WILSON, J.M. 1985. Ecology of the Crocodile Caves, Madagascar. Cave Science 12 (4): 135-138.

WILSON, J.M. 1987a. The Crocodile Caves of Ankarana, Madagascar. Oryx 21 (1): 43-47.

WILSON, J.M. 1987b. The Crocodile Caves of Ankarana: Expedition to Northern Mad, 1986. Cave Science 14 (3): 107-119. 